\title{
Orbital Secondary Lesion from Renal Cell Carcinoma
}

Greco $\mathrm{F}^{1^{*}}$, Sabatino $\mathrm{L}^{2}$, Casale $\mathrm{M}^{2}$ and Beomonte Zobel $\mathrm{B}^{1}$

${ }^{1}$ Unit of Diagnostic Imaging, Università Campus Bio-medico di Roma, Via Alvaro del Portillo, Rome, Italy

${ }^{2}$ Unit of Otolaryngology, Università Campus Bio-medico di Roma, Via Alvaro del Portillo, Rome, Italy

"Corresponding author: Federico Greco, Unit of Diagnostic Imaging, Università Campus Bio-medico di Roma, Via Alvaro del Portillo, 21, 00128, Rome, Italy, Tel: +3402650778; E-mail: federico.greco@unicampus.it

Received date: February 17, 2017; Accepted date: February 24, 2017; Published date: February 25, 2017

Copyright: (c) 2017 Greco F, et al. This is an open-access article distributed under the terms of the Creative Commons Attribution License, which permits unrestricted use, distribution, and reproduction in any medium, provided the original author and source are credited.

\section{Abstract}

The most common sites of metastasis of renal cell carcinoma are lungs, locoregional lymph nodes, bone and liver. Renal cell carcinoma rarely metastasizes in head and neck sites. We have reported a case of a patient of $47-$ year-old man who presented with unilateral blepharoptosis and blurred vision due to metastatic renal cell carcinoma to the orbit. The imaging techniques used have been fundamental for the diagnosis, staging and of the choice of the cytological sampling site.

Keywords Blepharoptosis; Kidney cancer; Orbital magnetic resonance imaging; Ptosis; Renal cell carcinoma

\section{Short Communication}

Kidney cancer constitutes the $2-3 \%$ of all malignant tumors in adults and the third most frequent cancer of the urinary tract [1-3]. Male-Female ratio is about two to one (M/F: 2:1), and the mean age at diagnosis is in the early 60 years $[2,4]$.

From 25 to $33 \%$ of patients with renal cell carcinoma (RCC) present metastasis at first diagnosis [5]; the most common localizations of metastatic sites are lungs (75\%), regional lymph nodes (65\%), bone and liver (both $40 \%$ ). Cases with metastatic localization in the head and neck region are $15 \%$ [6].

From $1 \%$ to $13 \%$ of orbital tumors is metastasis [7]. Studies conducted in different countries demonstrate as from $3 \%$ to $10 \%$ of the orbital metastasis (OM) derived from the kidney [8-11].

We have presented a case of a 47 -year-old patient with unilateral left blepharoptosis and blurred vision, due to an OM from RCC [12].

Brain magnetic resonance imaging (MRI) showed an expansive solid lesion located at the left orbit roof likely to be extraconal bone origin (diameters of $23 \times 15 \times 25 \mathrm{~mm}$ ). This lesion was isointense on T1 and T2-weighted images, showing contrast enhancement and intraorbital expansion at the upper-outer quadrant level. The lesions incorporated the lacrimal gland and were not visible cleavage planes from the upper rectus, lateral rectus and the upper eyelid muscle in (Figure 1).

Total body computed tomography (CT) showed in many secondary mediastinal lymphadenopathies, a partially exophytic lesion located in the upper pole of the left kidney (diameters $72 \times 56 \times 70 \mathrm{~mm}$ ) with necrosis in context that marks the upper caliceal group (Figures 2), two metastases at the body and medial arm of the left adrenal gland, a nodulation in the right adrenal gland, loco regional lumbar-aortic lymphadenopathy and many bone metastases in the skeletal portions studied. Consequently, cytology in specimens taken at the lymph-node stations 7 and $11 \mathrm{~L}$ through endoscopic ultrasound has placed diagnosis of RCC [12].

Orbital metastasis, generally, comes as orbital mass, exophthalmos, lid edema, ptosis, diplopia and/or cranial nerve paralysis [13].

In this case, symptoms such as blurred vision and unilateral ptosis hid a systemic malignancy. MRI and CT are very importance for the diagnosis, the staging of the disease and for the choice of the site where you can make the cytological or histological specimen. In our case the cytology confirmed the diagnosis of renal cell carcinoma [12].

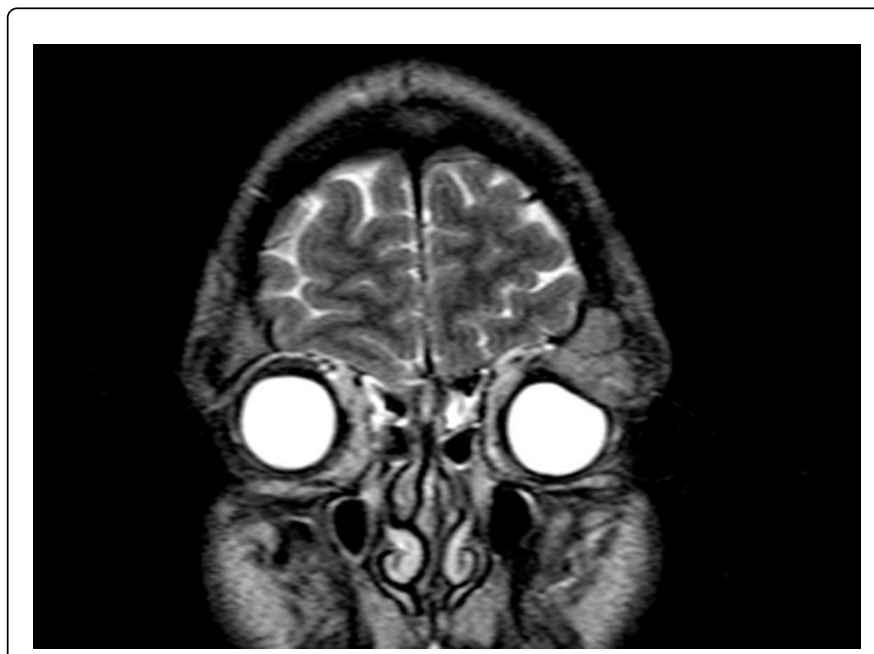

Figure 1: Magnetic resonance imaging: Coronal T2 TSE sequence showing expansive, isointense lesion of probable bone origin with intraorbital growth. 
Citation: Greco F, Sabatino L, Casale M, Beomonte Zobel B (2017) Orbital Secondary Lesion from Renal Cell Carcinoma . J Kidney 3: 140. doi:

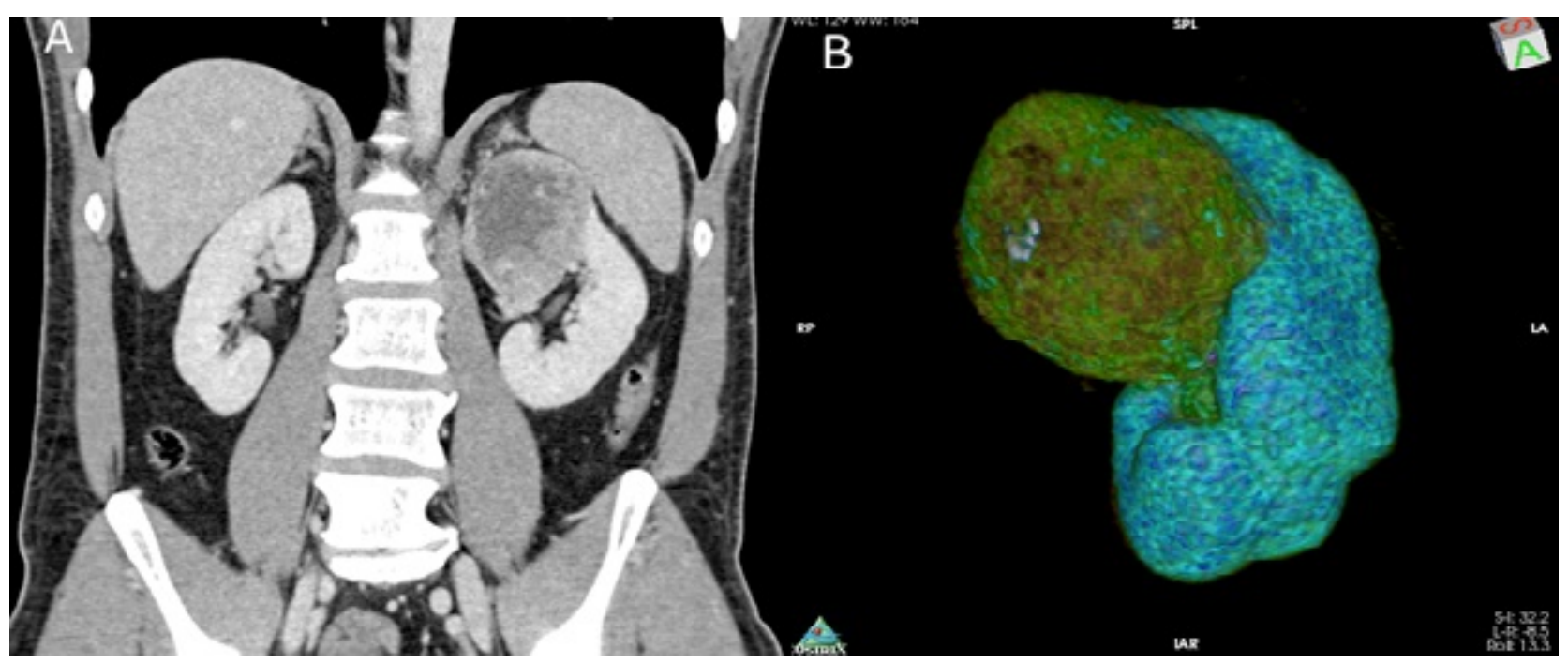

Figure 2: Computed tomography: Coronal scan during venous phase of the abdomen (A) and volume rendering reconstruction (B), show expansive lesion, partially exophytic, situated in the upper pole of the kidney with intralesional necrosis.

\section{References}

1. Butler BP, Novick AC, Miller DP, Campbell SA, Licht MR (1995) Management of small unilateral renal cell carcinomas: radical versus nephron-sparing surgery. Urology 45: 34-40.

2. McLaughlin JK, Lipworth L (2000) Epidemiologic aspects of renal cell cancer. Semin Oncol 27: 115-123.

3. Lee JH, You CH, Min GE, Park JS, Lee SB, et al. (2007) Comparison of the surgical outcome and renal function between radical and nephron sparing surgery for renal cell carcinomas. Korean J Urol 48: 671-676.

4. McLaughlin JK, Lipworth L, Tarone RE (2006) Epidemiologic aspects of renal cell carcinoma. Semin oncol 33: 527-533.

5. Airoldi M, Succo G, Valente G, Cavalot A, Gabriele P, et al. (1995) Head and neck metastases of renal cancer after nephrectomy: A report of 2 cases. Tumori 81: 213-214.

6. Matsumoto Y, Yanagihara N (1982) Renal clear cell carcinoma metastatic to the nose and paranasal sinuses. Laryngoscope 92: 1190-1193.
7. Civit T, Colnat-Coulbois S, Freppel S (2010) Orbital metastasis. Neurochirurgie 56: 148-151.

8. Shields JA, Shields CL, Brotman HK, Carvalho C, Perez N, et al. (2001) Cancer metastatic to the orbit: the 2000 Robert M. Curts Lecture. Ophthal Plast Reconstr Surg 17: 346-354.

9. Magliozzi P, Strianese D, Bonavolontà $\mathrm{P}$, Ferrara $\mathrm{M}$, Ruggiero $\mathrm{P}$, et al. (2015) Orbital metastases in Italy. Int J Ophthalmol 8: 1018-1023.

10. Yan J, Gao S (2011) Metastatic orbital tumors in southern China during an 18-year period. Graefes Arch Clin Exp Ophthalmol 249: 1387-1393.

11. Amemiya T, Hayashida H, Dake Y (2002) Metastatic orbital tumors in Japan: a review of the literature. Ophthalmic Epidemiol 9: 35-47.

12. Greco F, Sabatino L, Sabatino F, Casale M, Quattrocchi CC, et al. (2016) Unilateral blepharoptosis from renal cell carcinoma. J Kidney Cancer VHL 3: 11-15.

13. Kurli M, Finger PT (2005) The kidney, cancer, and the eye: current concepts. Surv Ophthalmol 50: 507-518. 